\title{
Nega in vzgoja mlajšega otroka kot pomembna temelja razvoja
}

\author{
Janja Perko \\ Osnovna šola Destrnik - Trnovska vas \\ janja.perko@gmail.com
}

\section{Zlatka Cugmas}

Univerza v Mariboru

zlatka.cugmas@um.si

\section{Mateja Pšunder \\ Univerza v Mariboru \\ mateja.psunder@um.si}

V prispevku nas zanimajo sodobna spoznanja o negi in vzgoji mlajšega otroka. Podrobneje predstavimo področja, vezana na najneposrednejše načine zadovoljevanja otrokovih potreb v najzgodnejšem obdobju, ki vplivajo na vzpostavljanje odnosa z otrokom. Ta odnos, ki ustvarja temelj kasnejše vzgoje v pravem pomenu besede, se začne vzpostavljati takoj po rojstvu otroka. Pozornost namenimo joku, spanju, telesnemu stiku in hranjenju. Ugotovimo, da je mnogo praks pri odnosu do dojenčka in malčka v današnjem času v nasprotju s praksami nekoč, kar je predvsem posledica družbenega napredka in znanstvenih spoznanj na področjih, ki so neposredno ali posredno povezana z odnosom do otroka. Nekatera spoznanja se tesno navezujejo na nego in vzgojo otroka v družini, druga so splošnejša, uporabna tudi v predšolskih institucijah. Pomembno je, da so s sodobnimi znanstvenimi pogledi na vzgojo in nego otroka seznanjene strokovne delavke oz. delavci v vrtcu, saj bodo le tako lahko svoje delo opravljali profesionalno.

Ključne besede: mlajši otrok, jok, hranjenje, telesni stiki, spanje

\section{Uvod}

Družina kot sistem obstaja v okolju, ki se nenehno spreminja, zato se nenehno spreminja tudi sama, z njo pa posledično zaznavanje in odnos do otrok ter načini vzgajanja, ki so prav tako odraz časa in prostora (Čačinovič Vogrinčič 1998; Švab 2001).

Socialni zgodovinarji pišejo, da se je pojem otroštva v Evropi izoblikoval med 16. in 18. stoletjem, na Slovenskem pa z zamikom šele v prejšnjem stoletju. Na Slovenskem je v 19. stoletju vladala izrazito avtoritarna vzgoja, ki je temeljila na strahospoštovanju in telesni kazni, otroci pa so bili pogosto žrtve zanemarjanja in nasilja. O začetkih občutenja otroštva in starševstva, kot ga 
poznamo danes, pri nas govorimo šele po drugi svetovni vojni (Puhar 1982; Rožman 2004; Škoro Babić idr. 2012).

$\checkmark$ prispevku obravnavamo nego in vzgojo mlajšega ${ }^{1}$ otroka danes. Danes zahvaljujoč znanosti neprimerljivo bolje poznamo potrebe otroka, kot so jih poznale generacije pred nami. Vemo, da jih je otroku treba zadovoljevati z veliko mero odzivnosti in občutljivosti, da bo lahko razvil varno navezanost. Pojave v odnosu mati - otrok, kot so zadovoljevanje dojenčkovih osnovnih potreb, materina odzivnost, razvijanje občutka varnosti in proces navezovanja v prvih mesecih otrokovega življenja, nekateri avtorji (Kompan Erzar in Poljanec 2009) strnejo v pojem stik z otrokom. Stik med otrokom in starši pomeni "sposobnost soustvarjanja edinstvenega čustvenega in fizičnega ritma, ki je za vsak par otrok - odrasli drugačen. Pomeni sposobnost matere in očeta, da prepoznata otrokove potrebe, njegov življenjski ritem, njegov način doživljanja in mu ga pomagata soustvariti« (Kompan Erzar in Poljanec 2009. 11). Avtorji pojasnjujejo, kako stik z otrokom udejanjiti skozi situacije, vezane na otrokov jok, hranjenje (dojenje), spanje in uravnavanje čustev. Omenjena področja zadovoljevanja otrokovih potreb so neločljivo povezana z materinimi in otrokovimi hormoni ter $z$ njunim neposrednim medsebojnim telesnim stikom, kar ima velik pomen za otrokov razvoj. $O$ tem in o pomenu posameznih področij zadovoljevanja otrokovih potreb z različnimi poudarki in v različnem obsegu pišejo tudi drugi avtorji (Bigelow idr. 2012; Hoyer 2011; Hrovat-Kuhar 2010; McKenna in McDade 2005; Sears in Sears 2004; 2008; Sunderland 2008; Zeifman 2001). Kot najpogostejše okoliččine, v katerih prihaja do neposrednega in intenzivnega vzpostavljanja stika z dojenčkom, omenjeni avtorji največkrat izpostavljajo dojenčkov jok, hranjenje, spanje in telesni stik.

V poljudni literaturi se je za posebej občutljiv in intenziven način zadovoljevanja dojenčkovih potreb v situacijah, kot so jok, dojenje, spanje in telesni stik, uveljavil termin povezovalno starševstvo (ang. attachment parenting) (Sears in Sears 2008; Šoster Olmer 1999), ki ga nekateri (Turgeon 2011) tudi kritizirajo oz. problematizirajo pretirano poudarjanje tovrstne prakse, čeprav ji zlahka najdemo znanstveno zaledje (Dewar 2008). Drži pa, da takšna praksa (ne glede na poimenovanje) od starša zahteva veliko mero občutljivosti, požrtvovalnosti, predanosti ter (začasnega) odrekanja lastnim interesom in udobju. V ospredje postavlja zadovoljevanje dojenčkovih potreb na čim naravnejši način, brez uporabe sodobnih pripomočkov in praks, ki staršem skrb

\footnotetext{
${ }^{1}$ V prispevku mlajši otrok predstavlja otroka v obdobju dojenčka in malčka, ki traja od rojstva do tretjega leta otrokove starosti (Zupančič 2009).
} 
za otroka sicer olajšajo, vendar pogosto na račun zmanjšanega ali celo onemogočenega stika $z$ dojenčkom.

Kljub ljudskemu reku, da se vzgoja otroka začne že v zibelki, $v$ tej začetni fazi še ne moremo govoriti o vzgoji otroka v pravem pomenu besede, hkrati pa je težko postaviti točno starostno mejo, kdaj naj bi se ta vendarle začela (Peček Čuk in Lesar 2011; Sunderland 2008). Zagotovo se odnos med starši in otrokom, ki ustvarja temelj kasnejši vzgoji v pravem pomenu besede in ima nanjo pomemben (čeprav le posreden) vpliv, začne vzpostavljati takoj po rojstvu otroka (Erzar in Kompan Erzar 2011; Sunderland 2008). Zato pri obravnavi vzgoje otroka začenjamo na začetku - v njegovem najzgodnejšem obdobju življenja.

\section{Dojenčkov jok}

Jok je dojenčkovo najpomembnejše sredstvo komuniciranja, kadar je v stiski, in vedno pomeni klic na pomoč odraslemu, naj se nemudoma odzove, mu pomaga zadovoljiti osnovne potrebe in poskrbi zanj (Kompan Erzar in Poljanec 2009; Sunderland 2008; Zeifman 2001). Če ga odrasli dosledno tolaži in njegov jok obravnava resno, v njegovih možganih nastanejo zelo učinkoviti sistemi za obvladovanje stresa tudi kasneje v življenju (Dawson 2000 v Sunderland 2008; Gunnar 1989 v Sunderland 2008). Dosledno odzivanje na dojenčkov jok pomeni dosledno odzivanje na potrebe otroka in zadovoljevanje le-teh. To po teoriji navezanosti spodbuja razvoj varne navezanosti, ki pozitivno vpliva na otrokov vsestranski razvoj, kar se pozitivno odraža tudi skozi kasnejše življenje v odraslosti. Varna navezanost ugodno vpliva na socialne in spoznavne zmožnosti otroka. Če je otrok varno navezan, lažje postane samostojen in razvija dobre odnose $z$ drugimi. Nasprotno otrok, ki ne razvije varne navezanosti, postane odvisen od drugih in negotov glede lastnih sposobnosti (Cugmas 1998; 2003; Erzar in Kompan Erzar 2011; Marjanovič Umek in Zupančič 2009; Kompan Erzar in Poljanec 2009; Papalia idr. 2003).

Nekateri svtorji (Puhar 1982; Rožman 2004; Sunderland 2008) pravijo, da so ljudje v preteklosti zagovarjali stališče, da je dojenčke in malčke najbolje pustiti jokati, saj so menili, da si ti tako »krepijo pljuča» in da jih odrasli samo »razvadijo«, v kolikor jih nenehno jemljejo v naročje. Še dandanes se mnogi sprašujejo, ali dojenček jok uporablja za to, da z njim manipulira s starši in uveljavlja oblast nad njimi. Dejstva o razvoju otrokovih možganov pričajo, da dojenček še nima dovolj razvitih spoznavnih sposobnosti za manipulacijo $z$ drugimi osebami (Kompan Erzar in Poljanec 2009; Sunderland 2008). Tudi nekateri drugi avtorji (Sroufe, Cooper in DeHart 1996 v Cugmas 1998) razmišljajo podobno, ko pravijo, da je odveč skrb, da bi dosledno in takojšnje od- 
zivanje na dojenčkov jok povzročilo, da bi ta začel jokati za vsako malenkost. Otrok se od odzivne in dosledne matere nauči, da bo ob njegovem doživljanju stresa vselej hitro in pravilno ukrepala. Tako bo sčasoma manj intenzivno izražal stres in manj jokal, saj bo vedel, da zelo močne reakcije niso potrebne. Omenjeno potrjujejo ugotovitve raziskave (Erdman in Caffery 2003), da so otroci mater, ki so se v prvih mesecih hitro in dosledno odzivale na njihov jok, pri enem letu manj jokali in so se hitreje pomirili kot otroci, ki so kot dojenčki morali čakati na materin odziv.

Ob tem danes obstajajo dokazi o občutljivosti dojenčkovih možganov na stres - ko joka, nadledvični žlezi izločata hormon kortizol, katerega raven v krvi se ob doslednem tolaženju spet zniža. V kolikor odrasli dojenčka pusti jokati in se na njegov klic na pomoč ne odzove, ostane raven kortizola ves čas visoka, kar na možgane deluje toksično in jih lahko trajno poškoduje. Znanstveniki takšen stres $v$ zgodnjem otroštvu pogosto povezujejo $s$ kasnejšimi težavami v odraslosti, ki se med drugim lahko kažejo kot anksioznost, depresivne motnje, nagnjenost $\mathrm{k}$ alkoholizmu, razne telesne bolezni itd. (Caldji, Diorio in Meaney 2000 v Sunderland 2008; Hsu idr. 2003 v Sunderland 2008).

Dojenčkov jok zahteva dosledno odzivnost odraslega, kar seveda ne pomeni, da je treba k otroku planiti v trenutku, ko se ta oglasi. Problematična je torej dolgotrajna stiska, ki jo otrok izraža z dolgotrajnim jokom, ki se običajno zaključi takrat, ko se otrok utrudi ali ko obupan ugotovi, da pomoči ne bo od nikoder (Sunderland 2008). Ko, skladno z otrokovim razvojem, jok, ki je $v$ začetku pomenil enega osnovnih načinov komunikacije, zamenja govor, otrok postopoma razvija sposobnost ubesedovanja svojih potreb, starši pa so postavljeni pred težko nalogo ločevanja med otrokovimi legitimnimi potrebami in zgolj željami (Sunderland 2008).

\section{Spanje}

Vprašanje, kje in kako bi moral otrok (za)spati, je za človeštvo nekaj novega. $\checkmark$ dveh milijonih let evolucije so namreč ljudje (kot vsi ostali primati) vedno spali skupaj s svojimi dojenčki. Kot vsi mladiči sesalcev bi hitro postali hrana plenilcem, če bi jih starši pustili nenadzorovane v temi (Sunderland 2008). Poleg tega so otrokovo spanje, njegov srčni utrip in dihanje stimulirani z dražljaji, ki jih oddajajo odrasli. To je verjetno posledica evolucije, da bi se kot vrsta kar najbolje prilagodili nevarnostim iz okolja (Chisholm 1986).

Ob pregledu raziskav (McKenna in McDade 2005; McKenna, Mosko in Richard 1997; Mosko, Richard in McKenna 1997) o spanju dojenčkov ugotovimo, da se je »moderni spalni model « razvil le v t. i. zahodni razviti družbi, ki od čim mlajših dojenčkov pričakuje čim prejšnjo samostojnost pri spanju. Avtorji 
opozarjajo na razkorak med naravnimi zakonitostmi glede spanja dojenčkov in družbenimi pričakovanji. Slednja so namreč posledica mitov, nerealnih pričakovanj in nepoznavanja biološkega razvoja naše vrste. Vse to pogosto vodi do tega, da starši v želji po dojenčkovem samostojnem spanju in uspavanju uporabljajo razne tehnike »učenja spanja« ter metode izjokavanja, ki na otrokov psihofizični razvoj ne vplivajo ugodno.

Potreba odraslih, da dojenček spi ločeno od njih, je verjetno posledica več sto- ali celo tisočletnih socialnih in bivanjskih sprememb ter spreminjanja vlog in nalog članov družine. Najverjetneje je takšna praksa posledica strahu in tisočletnih svaril pred t. i. "zaležanjem« dojenčka, ki naj bi bil v zgodovini večkrat vzrok smrti dojenčkov (Puhar 1982). Zato so v evropskem civilizacijskem prostoru v 9. stoletju "zaležanje« prvikrat opredelili kot kaznivo dejanje, materam pa s strani najvišjih cerkvenih dostojanstvenikov zapovedali ločeno ležišče za dojenčka. Prepričanje, da so matere s skupnim ležiščem svojim otrokom nevarne, je vztrajalo stoletja. A. Puharj (1982) se sprašuje o utemeljenosti tega strahu, saj v istem delu govori tudi o takratnih bivanjskih in socialnih razmerah ter odnosu do otrok, na podlagi česar bralec hitro podvomi v takratno, še bolj pa $v$ današnjo utemeljenost strahu pred tovrstno nevarnostjo za dojenčka.

Strokovnjaki so preučevali morebitno povezanost med sindromom nenadne smrti v zibki (SNSD) in skupnim spanjem. Ugotovitve raziskav (Kompan Erzar in Poljanec 2009; McKenna in McDade 2005; McKenna, Mosko in Richard 1997, Mosko, Richard in McKenna 1997; Sears in Sears 2008; Sunderland 2008) kažejo nasprotno, in sicer da se matere med spanjem zavedajo prisotnosti dojenčka in da je ob upoštevanju varnostnih ukrepov manjša verjetnost za SNSD, če mati in dojenček spita skupaj. V delih sveta, kjer je spanje z dojenčkom samoumevno, omenjenega pojava skorajda ne poznajo. Strokovnjaki skupno spanje odsvetujejo le $v$ določenih okoliščinah (npr. pri kadilcih, po konzumiranju alkohola, ob izčrpanosti itd.).

Dandanes materam nihče več ne zapoveduje, da dojenček nujno potrebuje svoje ležišče. Tudi skupno spanje jim je vedno pogosteje predstavljeno kot možnost. A v naši kulturi je postalo ločeno spanje nekaj samoumevnega in običajnega, prakticiranje skupnega spanja ima pogosto negativen predznak in je hitro označeno kot slaba vzgojna praksa, ki se ji je potrebno izogibati. Zdi se, da se starši bolj kot nesreče z zadušitvijo bojijo, da bodo otroka »razvadili«, če bodo spali skupaj z njim (Sears in Sears 2008).

Raziskovalci (Fifer in Moon 1994; McKenna in McDade 2005; McKenna, Mosko in Richard 1997, Mosko, Richard in McKenna 1997) ugotavljajo, da je zelo priporočljivo, da dojenček prve mesece spi v neposredni bližini staršev, saj 
ima naravno potrebo, da začuti telesno bližino matere, ki mu daje občutek varnosti in zaupanja. Tak način spanja, ki je popolnoma naraven, tudi materi pomaga, da se uglasi z otrokom in da skupaj sproščeno ustvarjata svoj odnos. Ugotovili so tudi (McKenna, Mosko in Richard 1997), da skupno spanje spodbuja dojenje, ki je dandanes, zaradi številnih ugodnih učinkov na otroka in mater, zelo zaželeno in spodbujano. Prav tako je znano (Sunderland 2008), da skupno spanje za otroka pomeni več telesnega stika z materjo, kar uravnava njegove telesne sisteme. Izsledki raziskav (Sunderland 2008) kažejo še, da so otroci, ki niso nikoli spali v isti postelji s starši, manj vodljivi.

Strokovnjaki (Pantley 2003; Sunderland 2008) poudarjajo, da bi moral dojenček oziroma malček ob uspavanju imeti občutek varnosti. $S$ tem se prepreči aktiviranje stresnih kemičnih snovi v njegovih možganih, otrok se počuti varnega in ljubljenega, ko zaspi. Obstajajo mehanizmi (npr. pomirjujoče vedenje odraslega, rutina), ki to pomagajo doseči ne glede na to, ali otrok spi sam ali s staršem.

\section{Telesni stik}

Tako kot dosledno odgovarjanje na dojenčkov jok in skupno spanje z dojenčkom tudi nudenje telesnega stika otroku nekateri ljudje označujejo kot slabo vzgojno prakso, ki vodi v t. i. razvajenost, predvsem ko govorimo o vsakokratnem pestovanju otroka $v$ naročju, ko ta pokaže potrebo po tem. Takšna miselnost je najverjetneje posledica vzgojne prakse v zgodovini, ki v obliki tovrstnih klišejev seže še $v$ današnji čas. V skladu z znanstvenimi ugotovitvami s področja otrokovega joka, spanja in razvoja varne navezanosti je nemogoče ravnati, v kolikor starši dojenčku oz. mlajšemu otroku nenehno odrekajo ali omejujejo telesne stike. Prav dotik je namreč prva poteza, ki jo instinktivno naredi mati, ki želi pomiriti jokajočega dojenčka in odgovoriti na njegove potrebe. Poleg tega je človekova potreba po telesnem stiku že dolgo prepoznana in priznana (Bigelow idr. 2012).

Strokovnjaki poudarjajo, da ima telesni stik (z materjo), še posebej stik kože $s$ kožo, blagodejen učinek na otrokov razvoj in da ga otrok nujno potrebuje. Telesni stik v njegovih možganih aktivira t. i. »hormone sreče« (oksitocin in opioide), ki znižujejo raven stresnih kemičnih snovi (Anisfeld idr. 1990; Bigelow idr. 2012; Kompan Erzar in Poljanec 2009; Sears in Sears 2008; Sunderland 2008).

Potreba po telesnem stiku je značilna za vse sesalce in človek ni nobena izjema. Mladiči oz. mlajši otroci se oklepajo varnega odraslega, kadarkoli se počutijo ogrožene. Za otroke takšno oklepanje ne pomeni, da se neprimerno vedejo ali da iščejo pozornost, temveč je to naravni način za zmanj- 
šanje stresa. Če se odrasli na otroka, ki ima željo po oklepanju zaradi stiske, odzivajo potrpežljivo in sočutno, je to dragocena naložba v njegovo sposobnost za neodvisnost kasneje $v$ življenju, kajti če se otrok počuti varnega v svetu, se vanj vključuje brez težav (Sunderland 2008). Raziskave o drugih sesalcih (Fleming, O'Day in Kraemer 1999) so med drugim pokazale, da so bili sesalski mladiči, ki so bili deležni veliko materinih dotikov, v odraslosti veliko pogumnejši od tistih, ki so bili deležni manj dotikanja - ti so bili kot odrasli veliko bojazljivejši in so se s stresom spopadali slabše kot mladiči iz prve skupine. Na pomen telesnega stika opozarja tudi dejstvo, ki ga je pokazala terapevtska praksa z osebami, ki so $v$ otroštvu utrpele pomanjkanje telesnega stika - te osebe imajo $v$ odraslosti različne težave, povezane $z$ vzpostavljanjem zadovoljujočih intimnih odnosov. Pomanjkanje ljubkovanja, tolaženja in dotikov v otroštvu se v odraslosti lahko kaže tudi kot samopoškodovanje, kajenje, motnje hranjenja, zloraba mamil in alkohola ter zanemarjanje telesa (Orbach 2004a; 2004b; v Sunderland 2008).

Da se bo otrok v odraslosti počutil varno ter da bo sprejemal sebe in druge, mu mora odrasla oseba v otroštvu zagotoviti varen telesni stik in telesno pomirjanje njegove stiske (Fleming, O'Day in Kraemer 1999). Vsaka oblika ljubečega telesnega stika med odraslim in otrokom ima lahko pozitiven vpliv na otrokov razvoj. Tako pri mlajših kot tudi pri starejših osebah je opaziti izjemen vpliv dotikov na delovanje možganov. Raziskave (Montagu 1971 v Sunderland 2008; Prescott 1971 v Sunderland 2008) kažejo, da imajo družbe in družine, kjer si družinski člani pogosto izkazujejo telesno naklonjenost, veliko manj težav $z$ jezo in agresijo.

Neomejenemu nudenju telesnih stikov otroku pritrjuje tudi teorija navezanosti, ki pravi, da je za razvoj varne navezanosti potrebno dosledno odgovarjanje na otrokove potrebe, kamor spada tudi potreba po telesnem stiku. Seveda ob poudarjanju zadovoljevanja te potrebe ni mišljeno, da je otroku telesni stik potrebno nuditi tudi takrat, kadar je povsem zadovoljen sam s seboj in ne izraža nobenih potreb po njem. $V$ takem primeru bi telesni stik na pobudo odraslega za otroka lahko pomenil vsiljivost, kar lahko doseže nasproten učinek in povzroči katerega izmed vzorcev t. i. nevarne navezanosti (Belsky Rovine in Taylor 1984 v Cugmas 1998).

\section{Hranjenje}

Glede hranjenja dojenčka so avtorji enotni (Hoyer 2011; Kompan Erzar in Poljanec 2009; Praper 1995; McKenna in McDade 2005), da je najboljša hrana zanj v prvih šestih mesecih izključno materino mleko, kot priporočata tudi Svetovna zdravstvena organizacija (SZO) (World Health Organization 1998) in 
UNICEF. Dojenje ima poleg prehrambene in zdravstvene vrednosti za otroka in mater še druge koristi. Ob njem se vzpostavljajo in krepijo čustvene vezi med njima. Dojenje lahko ima različne razsežnosti in ga opredelimo kot izključno dojenje, skoraj izključno dojenje, delno dojenje, minimalno dojenje in nikoli dojen. Razlogov, zakaj se dojenje ne vzpostavi ali se prekmalu prekine, je več. Eden izmed najpogostejših je pomanjkanje mleka, ki je v resnici le redko primarni razlog, temveč je $v$ večini primerov posledica drugih dejavnikov, najpogosteje pomanjkanja socialne opore materi in pravih informacij, ki so ključnega pomena pri vzpostavljanju in ohranjanju dojenja (Hoyer 2011; Hrovat Kuhar 2010; Kompan Erzar in Poljanec 2009; Sears in Sears 2009; Šoster Olmer 1999).

Čeprav je dojenje naravno, je z razvojem kulture postalo veščina, ki se je je potrebno naučiti. $V$ socialnih skupnostih, $v$ katerih so bili otroci $v$ davni preteklosti (ali kot je to pri preprostih ljudstvih še danes) že od rojstva vsakodnevno obkroženi $z$ doječimi materami, se je veščina dojenja prenašala iz generacije $v$ generacijo preko zgleda in učenja s posnemanjem. Danes se ženska prvič zares sreča z dojenjem šele takrat, ko sama postane mati (Šoster Olmer 1999).

Če dojenje povežemo s prejšnjimi temami (jok, telesni stik in spanje), ugotovimo, da so $v$ vzajemnem odnosu: dojenje $v$ primerjavi $z$ drugimi načini hranjenja omogoča takojšen odziv na dojenčkov jok, če je ta posledica lakote; vzpostavlja najtesnejši in najnaravnejši telesni stik ter je v vzajemnem odnosu s skupnim spanjem, saj skupno spanje olajša dojenje, dojenje spodbuja skupno spanje, vse skupaj spet olajša tolaženje otroka in odzivanje nanj. Praper (1995) ob zdravstvenih koristih dojenja za otroka navaja že omenjene psihološke koristi. Pravi, da je pomembno, da je narava poskrbela, da mora biti otrok pri dojenju aktiven. Dobro mora namreč prijeti in sesati, šcimer njegova samoaktivnost že na začetku postane pomemben dejavnik njegovega lastnega razvoja. S tem se nauči vložiti napor, ki ga pripelje do zadovoljitve potrebe. Z vidika znanja o objektnih odnosih vemo, da otrok v prvih mesecih potrebuje konstantni odnos v paru, zato je pomembno, da ga vsaj prvih šest mesecev hrani ena oseba, četudi hranjenje poteka po steklenički. Pomembno je, da ima ta oseba z otrokom dober stik in da ob hranjenju tečejo taktilna, očesna in gibalna komunikacija med skrbnikom in otrokom. To trditev potrjuje tudi raziskava (Heinrichs idr. $2001 \mathrm{v}$ Sunderland 2008), ki je pokazala, da tako dojenje kot hranjenje po steklenički, pri katerem oseba pestuje dojenčka ob svojem telesu, znižujeta raven stresnih hormonov in s tega vidika ni občutne razlike med obema načinoma hranjenja.

Čeprav nekateri avtorji (Folden Palmer 2007 v Kompan Erzar in Poljanec 2009) trdijo, da so dojeni otroci pogosteje varno navezani, druga raziskava 
(Britton 2006) tega ne potrdi. Iskali so namreč povezavo med dojenjem, varno navezanostjo otroka ter občutljivostjo matere. Ugotovili so, da neposredne povezave med dojenjem in vzorcem navezanosti ni in da so doječe matere pokazale večjo občutljivost za svoje otroke, kar spodbuja razvoj varne navezanosti. To je mogoče razložiti z drugo raziskavo (Heinrichs idr. 2001 v Sunderland 2008), ki je pokazala, da dojenje odlično vpliva na materino razpoloženje, ker pomirja sistem za odzivanje na stres v njenih možganih. Ker je mati mirna in sproščena, lažje pomiri in potolaži dojenčka. Iz tega lahko sklepamo, da ima dojenje vsaj posreden vpliv na razvoj varne navezanosti.

Raziskavi Kramerja idr. (2008) ter Quinna idr. (2001) kažeta, da izključno dojenje vsaj prvih šest mesecev pozitivno vpliva tudi na otrokov spoznavni razvoj. V vzdolžni raziskavi (Oddy idr. 2010) so raziskali vpliv izključnega dojenja vsaj prvih šest mesecev na kasnejše psihično zdravje otrok ter mladostnikov. Ugotovili so, da so manj kot šest mesecev dojeni oz. nedojeni otroci kasneje imeli več težav s psihičnim zdravjem in vedenjskih težav kot otroci, ki so bili izključno dojeni vsaj šest mesecev.

Vedenjski psihologi poudarjajo, da mati zadovoljuje otrokovo primarno biološko potrebo po hrani, njeno zadovoljevanje daje otroku občutek zadovoljstva. Navzočnost matere pri doživljanju tega zadovoljstva postane za otroka sekundarna potreba, saj vzljubi vse dražljaje, ki se pojavljajo skupaj s hranjenjem: materino toplino, nasmeh, besede ipd. (Berk 1996 v Cugmas 1998). Vendar za ustvarjanje čustvenega odnosa med materjo in otrokom ne zadostuje le materino zadovoljevanje otrokovih osnovnih bioloških potreb, temveč je potrebna širša interakcija med njo in otrokom. To potrjujejo tudi ugotovitve raziskav z opicami (Sroufe, Cooper in DeHart 1996 v Cugmas 1998), na podlagi katerih je mogoče sklepati, da otrok lahko razvije varno navezanost na mater, čeprav ga ta ne hrani (Berk 1996 v Cugmas 1998). Ta ugotovitev je pomirjujoča v primerih, kadar dojenje ne uspe ali to ni izvedljivo.

Glede na statistiko v Sloveniji (Nacionalni Inštitut za javno zdravje Republike Slovenije 2018; Fajdiga Turk 2013) je delež izključno dojenih dojenčkov v prvih mesecih še vedno na nezadovoljivi ravni oz. ni v skladu s priporočili SZO. Konec prvega meseca je izključno dojenih štiri petine dojenčkov, konec petega meseca štirje od desetih. Delež nedojenih otrok je višji pri materah z nižjim socialno-ekonomskim statusom in nižjo izobrazbo. Izsledki pilotske raziskave v Sloveniji kažejo, da se obdobje dojenja v Sloveniji podaljšuje. Povprečna dolžina dojenja je 10,2 meseca (Rebernik 2014). Današnjim materam je na področju dojenja na voljo bistveno več virov informacij in socialne opore, kot so je bile deležne matere prejšnjih generacij (Fleming, O'Day in Kraemer 1999).

Ob uspešni vzpostavitvi dojenja se kmalu porodi vprašanje o trajanju do- 
jenja. Večina priročnikov ter drugih strokovnih in znanstvenih virov (Hoyer 2011; Kompan Erzar in Poljanec 2009; Sears in Sears 2008; Šoster Olmer 1999) se opira na SZO in UNICEF, ki priporočata izključno dojenje vsaj prvih šest mesecev, nato ob drugi hrani še do dveh let ali dlje (t. i. podaljšano dojenje), $v$ kolikor to ustreza otroku in mami. Točne zgornje starostne meje SZO ne postavlja, saj večina otrok potrebo po dojenju preraste med drugim in četrtim letom starosti. Praper (1995) prav tako ne postavlja jasne starostne meje za odstavitev otroka od dojenja, ima pa drugačen pogled na način odstavljanja. Meni, da mora pobuda za odstavljanje zmeraj priti z materine strani, vendar postopoma. $Z$ vidika objektnih odnosov opozarja, da je podaljšano dojenje lahko tudi znak t. i. prolongirane in vampirske simbioze, ko mati vztraja pri dojenju iz lastnih potreb in otroka zapira v krog simbioze.

\section{Zaključek}

Pogledi na nego in vzgojo mlajšega otroka so se skozi zadnjih nekaj generacij postopoma in počasi, a korenito spremenili. Gre za posledico spremenjenega občutenja starševstva in odnosa do otroštva, ki temelji na znanstvenih spoznanjih na področju nege in vzgoje otrok ter na splošnem družbenem napredku. Znanost je ovrgla mnogo mitov iz preteklosti, nekateri se še ohranjajo. Slednji se najbolj odražajo v pojmovanju razvajenosti, saj se izraz pogosto uporablja neustrezno. Čeprav smo danes ob mnogih pričevanjih, ki govorijo o odnosu do otrok v preteklosti, osupli, pretreseni in prizadeti, menimo, da namen takratne vzgoje zagotovo ni bil otrokom škodovati. Bila je odraz časa, prostora in družbenih razmer. Enako velja za sodobno vzgojo in sodoben odnos do (mlajših) otrok. Še vedno ne vemo vsega in se še učimo. In prav tako menimo, da bi verjetno le izjemoma našli starše, ki bi pri skrbi za svojega otroka uporabljali določena sredstva z motivom škodovati otroku. Sklepamo, da starši poteze, ki niso optimalne za otrokov razvoj in medosebne odnose, izbirajo zato, ker drugače ne znajo, ne morejo ali imajo napačna prepričanja o negi in vzgoji.

Spoznanja, ki smo jih predstavili v tem prispevku, niso pomembna le pri vzgoji v družini, temveč imajo pomembno mesto tudi pri delu v vrtcu. Tudi tam otrok potrebuje zanesljive odrasle osebe, ki bodo sposobne razumeti njegove razvojne potrebe, prepoznati njegove stiske in strahove ter se znati nanje ustrezno odzvati.

\section{Literatura}

Anisfeld, E., V. Casper, M. Nozyce in N. Cunningham. 1990. »Does Infant Carrying Promote Attachment? An Experimental Study of the Effects of Increased 
Physical Contact on the Development of Attachment.« Child Development 61 (5): 1617-1627.

Belsky, J., M. Rovine in D. Taylor. 1984. »The Pennsylvania Infant and Famuly Development Project.« Child Development 55:718-728.

Berk, L. E. 1996. Children and Adolescents. 2. izd. Boston, MA: Allyn and Bacon.

Bigelow, A., M. Power, J. MacLellan-Peters, M. Alex in C. McDonald. 2012. »Effect of Mother/Infant Skin-to-Skin Contact on Postpartum Depressive Symptoms and Maternal Physiological Stress. « Journal of Obstetric, Gynecologic \& Neonatal Nursing 41 (3): 369-382.

Britton, J. R., H. L. Britton in V. Gronwaldt. 2006. »Breastfeeding, Sensitivity and Attachment.«Pediatrics 118 (5): 1436-1443.

Caldji, C., J. Diorio in M. J. Meaney. 2000. „Variations in Maternal Care in Infancy Regulate the Development of Stress Reactivity.« Biological Psychiatry 48 (12): 1164-1174.

Chisholm, J. 1986. Navajo Infancy: An Ethological Perspective. New York: Aldine de Gruyer.

Cugmas, Z. 1998. Bodi z menoj, mami: razvoj otrokove navezanosti. Ljubljana: Produktivnost, Center za psihodiagnostična sredstva.

- 2003. Narisal sem sonce zate: izbrana poglavja o razvoju otrokove navezanosti in samozaznave. Ljubljana: Center za psihodiagnostična sredstva.

Čačinovič Vogrinčič, G. 1998. Psihologija družine. Ljubljana: Znanstveno publicistično središče.

Dawson, G. 2000. »The Role of Early Experience in Shaping Behavioural and Brain Development and Its Implications for Social Policy.« Developmental Psychology 12 (4): 695-712.

Dewar, G. 2008. »The Science of Attachment Parenting.« http://www .parentingscience.com/attachment-parenting.html

Erdman, P., in T. Caffery. 2003. Attachment and Family Systems: Conceptual, Empirical and Therapeutic Relatedness. New York, NY: Brunner-Routledge.

Erzar, K., in K. Kompan Erzar. 2011. Teorija navezanosti. Celje: Celjska Mohorjeva družba.

Fajdiga Turk, V. 2013. »Bi lahko povečali delež izključno dojenih šestmesečnikov v Sloveniji?« http://www.nijz.si/sites/www.nijz.si/files/uploaded/picture1 -6970.pdf

Fifer, W. P., in C. M. Moon. 1994. »The Role of Mother's Voice in the Organization of Brain Function in the Newborn. "Acta Paediatrica 83 (397), 86-93.

Fleming, A. S., D. H. O'Day in G. W. Kraemer. 1999. »Neurobiology of MotherInfant Interactions: Experience and Central Nervous System Plasticity across Development and Generations." Neuroscience and Biobehavioral Reviews 23 (5): 673-685.

Folder Palmer, L. 2007. Baby Matters: What Your Doctor May Not Tell You about Caring for Your Baby. San Diego, CA: Baby Reference. 
Gunnar, M. R. 1989. »Studies of the Human Infant's Adrenocortical Response to Potentially Stressful Events.« New Directions for Child Development 45:3-18. Heinrichs, M., G. Meinlschmidt, I. Neumann, S. Wagner, C. Kirschbaum, U. Ehlert in D. H. Hellhammer. 2001. „Effects of Suckling on HPA Axis Responses to Psychosocial Stress in Postpartum Lactating Women. "The Journal of Clinical Endocrinology and Metabolism 86 (10): 4798-4804.

Hoyer, S. 2011. Uspešno dojenje za dobro zdravje otrok in mater. Ljubljana: Društvo UNICEF Slovenija.

Hrovat Kuhar, E. 2010. Poporodni izziv: ko dvojina postane množina. Ljubljana: Mladinska knjiga.

Hsu, F. C., G. J. Zhang, Y. S. Raol, R. J. Valentino, D. A. Coulter in A. R. Brooks-Kayal. 2003. »Repeated Neonatal Handling with Maternal Separation Permanently Alters Hippocampal GABAA Receptors and Behavioral Stress Responses."Proceedings of the National Academy of Sciences of the United States of America 14:12213-12218.

Kompan Erzar, K., in A. Poljanec. 2009. Rahločutnost do otrok: stik z otrokom v prvem letu življenja. Ljubljana: Brat Frančišek.

Kramer, M. S., F. Abound, E. Mironova, I. Valinovich, R. W. Platt in L. Matush. 2008. »Breastfeeding and Child Cognitive Development."JAMA 65 (5): 578-584.

Marjanovič Umek, L., in M. Zupančič. 2009. Razvojna psihologija. Ljubljana: Znanstvena založba Filozofske fakultete.

McKenna, J. J., in T. McDade. 2005. „Why Babies Should Never Sleep Alone: A Review of the Co-Sleeping Controversy in Relation to SIDS, Bedsharing and Breast Feeding." Paediatric Respiratory Reviews 6:134-152.

McKenna, J. J., S. Mosko in C. A. Richard. 1997. »Bedsharing Promotes Breastfeeding."Pediatrics 100 (2): 214-219.

Montagu, A. 1971. Touching: The Human Significance of the Skin. London: Harper and Row.

Mosko, S., C. A. Richard in J. J. McKenna. 1997. "Maternal Sleep and Arousals During Bedsharing with Infants."Sleep 20 (2): 142-150.

Oddy, W. H., G. E. Kendall, J. Li, P. Jacoby, M. Robinson in B. A. Psycha. 2010. »The Long-Term Effects of Breastfeeding on Child and Adolescent Mental Health: A Pregnancy Cohort Study Followed for 14 Years. «The Journal of Pediatrics 156 (4): 568-574.

Orbach, S. 2004a. »The Body in Clinical Practice, Part One: There's No Such Thing as a Body." In John Bowlby Memorial Lecture in Touch, Attachment and the Body, ur. Kate White, 17-34. London: Karnac.

Orbach, S. 2004b. »The Body in Clinical Practice, Part Two: When Touch Comes to Therapy. «In John Bowlby Memorial Lecture in Touch, Attachment and the Body, ur. Kate White, 35-47. London: Karnac.

Pantley, E. 2003. Otroško spanje - brez joka v sanje. Radovljica: Didakta.

Papalia, D. E., S. W. Olds in R. D. Feldman. 2003. Otrokov svet. Ljubljana: Educy. 
Peček Čuk, M., in I. Lesar. 2011. Moč vzgoje: sodobna vprašanja teorije vzgoje. Ljubljana: tehniška založba Slovenije.

Praper, P. 1995. Tako majhen, pa že nervozen!? Predsodki in resnice o nevrozi pri otroku. Nova Gorica: Educa.

Prescott, J. W. 1971. „Early Somatosensor Deprivation As an Ontogenetic Process in the Abnormal Development of Brain and Behaviour.«In Proceedings of the Second Conference on Experimental Medicine and Surgery in Primates, ur. E. I. Goldsmith in J. Mody-Janokowski, 356-375. Bazel: Karger.

Puhar, A. 1982. Prvotno besedilo življenja: oris zgodovine otroštva na Slovenskem $v$ 19. stoletju. Ljubljana: ČGP Delo.

Quinn, P. J., M. O'Callaghan, G. M. Williams, J. M. Najman, M. J. Andersen in W. Bor. 2001. »The Effect of Breastfeeding on Child Development at 5 Years: A Cohort Study." Journal of Paediatrics and Child Health 37 (5): 465-469.

Rebernik, A. 2014. Zakaj devet od desetih mater konča dojenje prej, kot bi si želele? Siol.net, 1. avgust. http://www.siol.net/trendi/intimno/druzina_in _prijatelji/2014/o8/dojenje_zalka_drglin.aspx

Rožman, I. 2004. Peč se je podrla! Kultura rojstva na slovenskem podeželju v 20. stoletju. Ljubljana: Slovensko etnološko društvo.

Sears, W., in M. Sears. 2004. Uspešen otrok. Radovljica: Didakta.

- 2008. Povezovalno starševstvo. Ljubljana: Mladinska knjiga.

Sroufe, L. A., R. G. Cooper in G. B. DeHart. 1996. Child Development: Its Nature and Course. 3. izd. New York: McGraw-Hill.

Sunderland, M. 2008. Znanost o vzgoji: praktični nasveti o spanju, joku, igri in ustvarjanju čustvenega ravnovesja za vse življenje. Radovljica: Didakta.

Nacionalni Inštitut za javno zdravje Republike Slovenije. 2018. "Svetovni teden dojenja 1. do 7. avgust 2018.« http://www.nijz.si/sl/svetovni-teden -dojenja-1-do-7-avgust-2018

Škoro Babić, A., M. Jeraj, M. Košir, B. Balkovec, M. Rebolj, D. Čeč. 2012. Zgodovina otroštva. Ljubljana: Zveza zgodovinskih društev Slovenije.

Šoster Olmer, K. 1999. Dojenje in materinstvo iz srca. Ljubljana: Vale Novak.

Švab, A. 2001. Družina: od modernosti k postmodernosti. Ljubljana: Znanstveno in publicistično središče.

Turgeon, H. 2011. »How Much Attachment Parenting Is Necessary? The Real Keys to Bonding.«http://www.babble.com/baby/how-much-attachment -parenting-is-necessary/

World Health Organization. 1998. Evidence for the Ten Steps to Successful Breastfeeding. Geneva: World Health Organization.

Zeifman, D. M. 2001. »An Ethological Analysis of Human Infant Crying." Developmental Psychobiology 39:265-285.

Zupančič, M. 2009. »Predmet in zgodovina razvojne psihologije.« V Razvojna psihologija, ur. L. Marjanovič Umek in M. Zupančič, 6-27. Ljubljana: Filozofska fakulteta. 


\section{Care and Education of a Young Child as an Important Developmental Basis}

The focus of the article is on care and education of a child. The areas where the most direct ways of satisfying the need of a child in his or hers earliest period that affect establishing the relationship with the child are presented in more detail. This relationship is established right after child's birth and represents a basis for later upbringing. Cry, sleep, physical contact and feed are being taken into the account. We find that many practices in relation to infants and toddlers in the present day are in great contradiction with practices in the past, which is largely a consequence of social progress and scientific knowledge in areas that are directly or indirectly related to the attitude towards children. Some findings are highly related to child's family care and upbringing, whereas more general ones can be used in preschool education institutions. What is important is that professional preschool teachers and workers are familiarized with modern scientific views of child's upbringing, education and care since then their work can be done professionally.

Keywords: young child, crying, feeding, body contact, sleeing 